\title{
Relationship between Economic Growth and Employment in Vietnam
}

\author{
Phạm Hồng Mạnh \\ Nha Trang University - phmanhdhnt@gmail.com \\ Nguyễn Văn Ngọc \\ Nha Trang University - ngvng@yahoo.com \\ Hạ Thị Thiều Dao \\ Banking University HCMC - thieudao08@gmail.com
}

\begin{tabular}{|c|c|}
\hline ARTICLE INFO & ABSTRACT \\
\hline $\begin{array}{l}\text { Article history: } \\
\text { Received: } \\
\text { Dec. 22, } 2013 \\
\text { Received in revised form } \\
\text { Jan. 24, } 2014 \\
\text { Accepted: } \\
\text { Sep. 30, } 2014 \\
\end{array}$ & $\begin{array}{l}\text { The paper examines the relationship between employment and } \\
\text { economic growth during the period } 1991-2012 \text { in Vietnam and } \\
\text { obtains forecasts for employment from } 2013 \text { to } 2020 \text {, using theories } \\
\text { of production function for establishment of econometric models. The } \\
\text { results show that the employment elasticities of economic growth } \\
\text { are }-0.49 \text {; } 0.55 \text { and } 0.66 \text { for agriculture, manufacturing and service } \\
\text { sectors respectively and } 1.71 \text { for Vietnamese economy as a whole in } \\
\text { the period. The results also indicate that an annual growth rate of } 6 \% \\
-7 \% \text { can help create from } 55.322 \text { to } 56.243 \text { million jobs by } 2015 \text { and } \\
\text { from } 61.739-64.519 \text { million ones by } 2020 \text {. Additionally, the } \\
\text { research offers several important policy recommendations to } \\
\text { promote economic growth and job creation in Vietnam in the next } \\
\text { period. }\end{array}$ \\
\hline
\end{tabular}




\section{INTRODUCTION}

After over 25 years of economic reform, Vietnam has escaped from poverty, backwardness and underdevelopment and started an extensive, intensive and overall integration into the world economy. To reach such achievements, the government has reformed its management mechanism, developed a multi-sector economy, and made the best use of internal and external resources to promote the socioeconomic development. In this development, employment policy plays an important role in both individual and social life.

Labor market can either promote or restrict economic growth. Hence, examining the relationship between economic growth and employment is one of the important tasks for policy makers. This problem has been explored from different aspects for years: factors affecting employment in Vietnam by Đặng (2002), impacts of economic growth on employment in different European countries by Herman (2011), Andrea et al. (1995), Padalino et al. (1997), and Seyfried (2003), etc.

Most researches in Vietnam employ qualitative approaches whereas economic models are used by some foreign researchers for examining the employment elasticity of growth. The socioeconomic development strategy adopted by the Vietnamese government for the period 2011-2020 sets a target growth rate of 7\% $8 \%$ per year (Vietnam's Government, 2011). Hence, the question is how many jobs are needed to improve personal income and living standard.

To find answers to the aforementioned question, the paper examines the relationship between economic growth and employment in Vietnam for the coming years, which is considered to be a basis for prediction of job creation as well as the policy on employment in each sector and the national economy up to 2020 .

\section{THEORETICAL BASES AND METHODS}

\subsection{Theoretical bases}

Economic growth has been much discussed by researchers. According to Phan (2006), economic growth is an increase in overall output of an economy in a given period. Thus, it can be understood as an increase in GDP or GNP or personal income in a given period. Economic growth reflects a quantitative change in an economy.

Labor is a special commodity that can be traded in the market like other services (Phan, 2006). Employees, another concept relating to labor, are defined as "people 
from 15 years old and above, capable of working, working under labor contracts, receiving salaries and subject to the management of the employers" (Vietnam's National Assembly, 2012).

Employment is considered as an important macroeconomic category. According to Vietnam's Labor Code, “employments are activities that generate incomes that the law does not prohibit." (Vietnam's National Assembly, 2012). Employment is measured by such indexes as employment or unemployment rates, structure of jobs by industries, economic sectors, or demographic features, etc. Employment can be examined from extensive and intensive economic growth. Regarding extensive growth, employment is more important than the quality of the labor force, and economic development is determined by ways of making use of idle labor while the intensive growth depends on education, R\&D, IT and innovation. Thus, to promote intensive economic growth, it is essential to enhance public education level and quality of workforce, etc.

Various models are used to determine the relationship between economic growth and employment. Kapos (2005) and Dopke (2001) find a positive relationship between them in which economic growth can create new jobs at a level varying over periods and countries. This reflects different reactions by labor markets to the economic growth. Schmid (2008) suggests that both extensive and intensive growth models are important to the possibility of job creation. Thus, economic growth as a reaction to increases in aggregate demand can be achieved in different situations, such as increases in inputs, productivity of factors or both of them.

Kapos (2005) finds the relation between growth rates and employment in many countries and estimates employment elasticity, thereby predicting employment status in these countries. In addition, Herman (2011) examines the effect of economic growth on employment and income in EU countries between 2000 and 2010. The main findings of this paper show "the existence of a low employment elasticity of economic growth in EU, but this has significant differences from one country to another."

However, concerning economic theories on the relationship between economic growth and labor, most economists agree that four important factors affecting economic growth are capital (K), labor (L), natural resource (R) and technology (T). According to Đinh et al. (2008), the relationship can be generalized through the following production function:

$$
\mathrm{Y}=\mathrm{F}(\mathrm{K}, \mathrm{L}, \mathrm{R}, \mathrm{T})
$$


The factors $\mathrm{K}$ and $\mathrm{L}$ can be directly measured and the factor $\mathrm{R}$ is considered as a supplement to the accumulated capital $(\mathrm{K})$. Thus, the production function can be rewritten as $\mathrm{Y}=\mathrm{F}(\mathrm{K}, \mathrm{L})$.

In this paper, production function is used to analyze the relationship between economic growth and employment in Vietnam as well as predict trend of job creation in the next period.

\subsection{Research Methods}

Approach: As the most suitable functional form for analysis of the origin of growth, Cobb-Douglas production function is used by most researchers to examine the relationship between economic growth and employment, which is performed as follows:

$$
Y=A L^{\alpha} K^{\beta}
$$

Where:
A: total factor productivity
L: labor input
$\alpha$ : elasticity of output with respect to labor
$\beta$ : elasticity of output with respect to capital

Sum of two elasticity coefficients $(\alpha+\beta)$ shows returns to scale of the production function, if:

$(\alpha+\beta)>1$, returns to scale are increasing

$(\alpha+\beta)<1$, returns to scale are decreasing

And if $(\alpha+\beta)=1$, returns to scale are constant.

From the production function (2), the transcendental logarithmic function is generalized as follows:

$$
\begin{aligned}
& \ln Y=\ln A+\alpha L+\beta K \\
& \left(\frac{\partial Y}{Y}\right)=(\alpha)\left(\frac{\partial L}{L}\right)+(\beta)\left(\frac{\partial K}{K}\right)+\left(\frac{\partial A}{A}\right)
\end{aligned}
$$

The function (4) is used to determine the output elasticity of labor in respond to different scenarios of GDP growth rate and indicate the relationship between the amount of employment in prediction and the amount of employment in reality. 
Data: The paper uses data on growth and employment in Vietnam during the period 1991-2012 collected by the General Statistics Office of Vietnam (GSO).

\section{RESEARCH RESULTS AND DISCUSSION}

\subsection{Overview of Sample}

From 1991 to 2012 statistics show that the highest GDP of Vietnam is VND2,412,778 billion, the lowest is VND548,063 billion and the average is VND1,322,104.5 billion (according to 2010 constant price). Contribution from agriculture to the GDP reaches the highest value of VND435,414 billion, the lowest of VND168,449 billion and the average of VND285,703.6 billion; whereas contribution from manufacturing sector to the GDP reaches the highest, lowest and average values of VND930,593 billion, VND140,448 billion and VND479,412 billion respectively.

During the period of 1991-2012, the biggest number of job created was 51.699 million and 30.135 million was the lowest, and the average is 39.580 million jobs per year. These figures in agriculture sector are 25.045 million, 21.907 million and 23.967 million respectively; in manufacturing sector: 10.955 million, 3.390 million and 6.318 million; and in service sectors 16.256 million, 4.837 million, and 9.294 million respectively. The output and employment statistics of the economy and sectors are shown in Table 1.

Table 1. Gross Domestic Income, Capital and Labor by Sector in 1991 - 2012

\begin{tabular}{|c|c|c|c|c|c|c|c|c|c|c|c|c|}
\hline \multirow[t]{2}{*}{ Year } & \multicolumn{4}{|c|}{$\begin{array}{c}\text { GDP (VND billion) } \\
\text { (in } 2010 \text { constant price) }\end{array}$} & \multicolumn{4}{|c|}{$\begin{array}{l}\text { Capital (VND billion) } \\
\text { (in } 2010 \text { constant price) }\end{array}$} & \multicolumn{4}{|c|}{ Labor (thousand people) } \\
\hline & Total & Agri. & Manu. & Serv & Total & Agri. & Manu. & Ser & Total & Agri. & Manu. & Service \\
\hline 1991 & 548,063 & 168,449 & (10, & 6 & 59,354 & (1) & 26,116 & & 30,135 & 21,907 & 3,390 & 4,837 \\
\hline 1992 & 595,743 & 180,036 & 158,409 & 257,299 & 90,828 & & 44,415 & 34,878 & 30,856 & 22,340 & 3,474 & 5,043 \\
\hline 1993 & 643,868 & 185,939 & 178,407 & 279 , & 123,891 & 11,026 & 68,511 & 44 & 31,579 & 22,756 & 3,562 & 5,262 \\
\hline 1994 & 700,745 & 192,199 & 202,294 & 306, & 122,691 & 11,533 & 47,8 & 63,309 & 32,303 & 23,156 & 3,655 & 5,493 \\
\hline 1995 & 767,599 & 201,427 & 229,808 & 336,364 & 137,284 & 18,219 & 46,777 & 72,288 & 33,031 & 23,535 & 3,756 & 5,740 \\
\hline 1996 & 839,293 & 210,289 & 263,037 & 365,966 & 157,722 & 20,571 & 56,757 & 80,394 & 33,761 & 23,874 & 3,888 & 5,999 \\
\hline 1997 & 907,710 & 219,388 & 296,235 & 392,087 & 188,056 & 24,640 & 63,689 & 99,726 & 34,493 & 24,196 & 4,021 & 6,276 \\
\hline 1998 & 960,038 & 227,124 & 320,923 & 411,991 & 193,034 & 24,671 & 68,668 & 99,695 & 35,233 & 24,504 & 4,157 & 6,572 \\
\hline 1999 & $1,005,866$ & 239,013 & 345,584 & 421,270 & 211,927 & 29,980 & 78,375 & 103,572 & 35,976 & 24,792 & 4,300 & 6,884 \\
\hline 2000 & $1,074,137$ & 250,089 & 380,383 & 443,666 & 234,808 & 33,822 & 86,366 & 114,620 & 36,702 & 25,045 & 4,445 & 7,212 \\
\hline
\end{tabular}




$\begin{array}{llllllllllllll}2001 & 1,148,198 & 257,550 & 419,919 & 470,728 & 274,633 & 38,852 & 97,236 & 138,545 & 38,180 & 24,244 & 5,383 & 8,552 \\ 2002 & 1,229,493 & 268,281 & 459,715 & 501,496 & 314,251 & 27,540 & 133,044 & 153,667 & 39,276 & 24,312 & 6,048 & 8,916 \\ 2003 & 1,319,748 & 277,996 & 507,890 & 533,862 & 354,918 & 29,997 & 146,562 & 178,359 & 40,404 & 24,323 & 6,667 & 9,414 \\ 2004 & 1,422,555 & 290,124 & 559,787 & 572,645 & 401,762 & 33,546 & 163,846 & 204,370 & 41,579 & 24,407 & 7,193 & 9,979 \\ 2005 & 1,588,646 & 342,811 & 605,516 & 640,319 & 447,135 & 31,320 & 195,730 & 220,085 & 42,775 & 23,563 & 7,524 & 11,688 \\ 2006 & 1,699,501 & 355,831 & 649,657 & 694,013 & 516,382 & 39,077 & 221,946 & 255,360 & 43,980 & 24,365 & 8,488 & 11,127 \\ 2007 & 1,820,667 & 369,905 & 697,499 & 753,263 & 656,057 & 43,994 & 284,727 & 327,336 & 45,208 & 23,932 & 8,565 & 12,711 \\ 2008 & 1,923,749 & 387,262 & 726,329 & 810,158 & 707,225 & 50,325 & 294,844 & 362,055 & 46,461 & 24,303 & 8,986 & 13,172 \\ 2009 & 2,027,591 & 394,658 & 769,733 & 863,200 & 762,843 & 47,401 & 319,516 & 395,926 & 47,744 & 24,606 & 9,562 & 13,576 \\ 2010 & 2,157,828 & 407,647 & 824,904 & 925,277 & 830,278 & 51,062 & 355,442 & 423,774 & 49,049 & 24,279 & 10,277 & 14,493 \\ 2011 & 2,292,483 & 424,047 & 879,994 & 988,442 & 770,087 & 46,821 & 330,882 & 392,384 & 50,352 & 24,363 & 10,719 & 15,270 \\ 2012 & 2,412,778 & 435,414 & 930,593 & 1,046,771 & 785,755 & 40,781 & 343,159 & 401,815 & 51,699 & 24,488 & 10,955 & 16,256\end{array}$

Source: Authors' calculations from data of GSO (2013b)

\subsection{Results from the Model of Relationship between Employment and Economic Growth}

The results show that the average growth rate was 7.3\%/year in $1991-2012$ period, - or $9.5 \%$ in manufacturing sector; $7 \%$ in service sector and $4.7 \%$ in agricultural sectors, to be more precise. However, the growth rate tended to decrease from approximately $8 \%$ in the early years of this period to $5.8 \%$ in the last five years. The growth rate was rather stable in service sector and fell remarkably in manufacturing and agricultural sectors (to $5.9 \%$ and $3.3 \%$ per year respectively).

It is worth noting that the labor market experienced only slight changes in this period when job creation increased by $2 \%$ to $4 \%$ per year (this increase was $6 \%$ and $0.5 \%$ in manufacturing and service sector respectively). Moreover, the growth of employment in the agricultural sector shows a downward tendency and even a negative growth rate at times. This shows that manufacturing and service can attract labor from the agricultural sector according to the Lewis theory of economic growth (Todaro \& Smith, 2009).

The increase in labor's income is at an average rate of $4.6 \% / y e a r$ and has a tendency to fall in this period. In the last five years this rate is 3\%/year, and in 2012 it raises by only $2 \%$ compared to 2011 . 
The analysis of the result indicates a highly positive correlation between economic growth and income $(\mathrm{R}=0.97)$, which explains that economic growth helps improve the workers' income. The correlation, however, between economic growth and employment is not obvious in recent years particularly, reflecting the quality of growth of the economy as a whole. The factor capital/technology (not labor) is considered to be a strong driving force for economic development. The results of this analysis are presented in Table 2 .

Table 2. Estimate Results

\begin{tabular}{llccc}
\hline Variable & Symbol & $\begin{array}{c}\text { Regression } \\
\text { coefficient }\end{array}$ & \multicolumn{2}{c}{ Statistical value } \\
\cline { 3 - 4 } & & $\mathbf{t}$ & Sig. \\
\hline
\end{tabular}

Model 1: Production function $Y=0.001132 * K^{0.22} * L^{1.71}$

Obs. $n=22 ; R^{2}$ Adj= 0.99; Thống kê F-statistics =2354.61; Sig. $F=0.000$

Total factor productivity

$\begin{array}{lll}\text { TFP } & 0.001132 & -3.7235\end{array}$

Output elasticity of labor

$\alpha \quad 1.71$

7.3952

.000

Output elasticity of capital

$\beta \quad 0.22$

4.3743

.000

Model 2: Agricultural production function $Y=1.89 * 10^{20} * K^{0.75 *} \mathbf{L}^{-4.19}$

Obs. $n=22 ; R^{2}$ Adj=0.87; F-statistics $=71.11 ;$ Sig. $F=0.000$

Total factor productivity

TFP

$1.89 * 10^{20}$

3.7920

.000

Output elasticity of labor

A $\quad-4.19$

$-3.216$

.001

Output elasticity of capital

B

0.75

9.0532

.000

Model 3: Manufacturing production function $Y=24.33 * K^{0.43 *} L^{0.55}$

Obs. $n=22 ; R^{2}$ Adj= 0.94; F-statistics =174.56; Sig. $F=0.000$

Total factor productivity

TFP 24.33

3.0434

.007

Output elasticity of labor

$\begin{array}{ll}\alpha & 0.55\end{array}$

1.5245

.144

Output elasticity of capital

$\beta$

0.43

2.2809

.034

Model 4: Service production function $Y=92.74 * K^{0.22} * L^{0.66}$

Obs. $n=22 ; R^{2}$ Adj= 0.99; F-statistics $=1026.21 ;$ Sig. $F=0.000$

Total factor productivity

TFP $\quad 92.74$

11.3991

.000

Output elasticity of labor

$\alpha \quad 0.66$

6.4192

.001

Output elasticity of capital

$\beta \quad 0.22$

4.5559

.000

Source: Authors' calculation using Data Analysis in MS Excel 2010. 
The results of the analysis of regression models show that F-statistic and t-statistic indicate an appropriate presence of input data.

Regarding the national economy, $\alpha$ equaling 0.22 implies that a $1 \%$ increase in capital makes GDP rise by $0.22 \%$; and $\beta$ equaling 1.71 implies that a $1 \%$ increase in labor results in a growth rate of $1.71 \%$. The sum of $(\alpha+\beta)>1$ explains that production function exhibits increasing returns to scale. The economic growth rate is higher than that of both labor and capital.

In agriculture, $\alpha$ equaling 0.75 implies that a $1 \%$ increase in capital makes agricultural output rise by $0.75 \%$; and $\beta$ equaling -4.19 implies a $1 \%$ increase in labor makes the output fall by $4.19 \%$. This is totally appropriate to the law of diminishing marginal product. The sum of $(\alpha+\beta)<1$ indicates decreasing returns to scale. The growth of agricultural output is lower than that of labor and capital.

In manufacturing sector, $\alpha$ equaling 0.43 implies that a $1 \%$ increase in capital makes industrial output rise by $0.43 \%$; and $\beta$ equaling 0.55 implies a $1 \%$ increase in labor results in an increase of $0.55 \%$ in industrial output. The $\beta$ value, however, is not statistically significant (sig. $=0.144>5 \%$ ), implying that labor does not affect the economic growth in the surveyed period while TFP plays a more important role.

In service sector, $\alpha$ equals 0.22 , showing an increase of $1 \%$ in capital leads to a growth of $0.22 \%$ in output while $\beta$ value of 0.66 shows that an increase of $1 \%$ in labor makes output rise by $0.66 \% ;(\alpha+\beta=0.88)<1$ indicates decreasing returns to scale. The growth rate of the service sector is lower than that of labor and capital.

\subsection{Prediction of employment in 2013-2020}

According to the socioeconomic development strategy adopted by the Vietnamese Government for the period 2010-2020, the economic growth rate is expected to reach $7-8 \%$ year (Government, 2011). The above econometric models can help us make predictions of job creation in the coming period.

In reality, the Vietnamese growth rate in 2012 and 2013 is relatively low, below 6\% while the government strategy aims at a growth rate of $7 \%$ or $8 \%$; therefore, to be consistent with the present situation, the paper suggests one more scenario for the period 2013-2020 with the growth rate of 5\% and 6\%. The prediction of job creation in the next period is presented in Table 3 below: 
Table 3. Scenarios of Growth and Employment in Vietnam during 2013-2020

\begin{tabular}{ccccccc}
\hline & \multicolumn{2}{c}{ Growth rate of 5\% } & \multicolumn{2}{c}{ Growth rate of 6\% } & \multicolumn{2}{c}{ Growth rate of 7\% } \\
\cline { 2 - 7 } Year & $\begin{array}{c}\text { GDP, } \\
\text { VND billion } \\
\text { (2010 price) }\end{array}$ & $\begin{array}{c}\text { Employment } \\
\text { (thousand } \\
\text { people) }\end{array}$ & $\begin{array}{c}\text { GDP, VND billion } \\
\text { (2010 price) }\end{array}$ & $\begin{array}{c}\text { Employment } \\
\text { (thousand } \\
\text { people) }\end{array}$ & $\begin{array}{c}\text { GDP, VND billion } \\
\text { (2010 price) }\end{array}$ & $\begin{array}{c}\text { Employment } \\
\text { (thousand } \\
\text { people) }\end{array}$ \\
\hline 2012 & $2,412,778$ & 51,796 & $2,412,778$ & 51,796 & $2,412,778$ & 51,796 \\
2013 & $2,533,417$ & 52,652 & $2,557,545$ & 52,945 & $2,581,672$ & 53,238 \\
2014 & $2,660,088$ & 53,522 & $2,710,997$ & 54,120 & $2,762,390$ & 54,720 \\
2015 & $2,793,092$ & 54,407 & $2,873,657$ & 55,322 & $2,955,757$ & 56,243 \\
2016 & $2,932,747$ & 55,306 & $3,046,077$ & 56,549 & $3,162,660$ & 57,809 \\
2017 & $3,079,384$ & 56,220 & $3,228,841$ & 57,804 & $3,384,046$ & 59,418 \\
2018 & $3,233,353$ & 57,149 & $3,422,572$ & 59,087 & $3,620,929$ & 61,072 \\
2019 & $3,395,021$ & 58,094 & $3,627,926$ & 60,398 & $3,874,394$ & 62,772 \\
2020 & $3,564,772$ & 59,054 & $3,845,602$ & 61,739 & $4,145,602$ & 64,519 \\
\hline
\end{tabular}

Source: Authors' calculations from dataset of GSO

According to constructed scenarios, 54,407 million new jobs are created by 2015 and 59,054 million created by 2020 if the economic growth rate is $5 \%$. Meanwhile, 55,322 million and 61,739 million jobs will be created by 2015 and 2020 respectively with an assumption that the average economic growth rate will be $6 \%$ per year. With a rate of $7 \%$, the number of newly created jobs will be 57,809 million by 2015 and 64,519 million by 2020 .

\section{CONCLUSION AND RECOMMENDATIONS}

The research results show that there really exists a relationship between employment and economic growth, which allows a prediction about jobs created for 54,407 and 59,054 million people by 2015 and 2020 respectively if the average growth rate is $5 \%$ year. These figures will be 55,322 and 56,243 million jobs by 2015 ; and 61,739 and 64,519 million jobs by 2020 respectively for the growth rate of $6 \%$ and $7 \%$.

Perhaps, a scenario for the economy with the average growth rate of $6-7 \%$ is feasible for present economic situation. Through the aforementioned results, authorities should consider the following issues to ensure high employment rates in the future:

First, policies on macroeconomic stability that Government is implementing should be consistent in order to promote economic growth. Macroeconomic stability is an 
essential precondition for ensuring employment and income for Vietnamese laborers in the future. In the period 2013-2020, hence, it is necessary to focus on such specific measures as: Maintaining steady growth rate, implementing strict financial policy, reducing budget expenditures, orienting investment toward national key projects; adopting flexible monetary policies, controlling growth of credit and reducing inflation; supporting the frozen real estate market, and helping companies deal with difficulties, etc.

Second, there should be new policies encouraging investment. Economic growth is considered as a basis for improving employment status and increasing income. In order to maintain a high growth rate until 2020, it is essential to focus on measures to mobilize all possible resources, such as financial resource from economic sectors as well as natural resources, etc.

Third, policies on employment support need to be implemented more effectively due to the fact that Vietnam is entering a period of demographic bonus and about one million people reach working age annually. These policies should focus on extending production in manufacturing and construction sector, especially small scale and laborintensive industries, encouraging development of private sector, and supporting selfemployment in rural areas. Additionally, enhancing performance of the employment centers is also a solution to reduce unemployment rate.

Finally, vocational training courses should be promoted to improve labor productivity. Despite remarkable achievements in 1991-2012, Vietnam only followed an extensive growth model that proved to be defective and inappropriate to new economic conditions. In 2013-2020, however, Vietnam's Government adopts an intensive growth model. In the next period, vocational training should be promoted in response to changes in technology, organization, or management, etc. Training process could be implemented by companies or local training centers.

This paper only examined national economy and basic economic sectors due to difficulties in collecting data on employment status and economic growth in Vietnam. Thus, the research could not examine data of specific provinces and economic regions. Future researches may have to pay attention to this aspect 


\section{References}

Boltho, A. \& A. Glyn (1995), “Can Macroeconomic Policies Raise Employment?” International Labour Review, 134(4-5): 451-470.

Dopke, J. (2001), “The Employment Intensity of Growth in Europe”, Kiel Working Paper, 1021, retrieved from http://www.ifw-members.ifw-kiel.de/publications/theemployment-intensity-ofgrowth-in-europe/kap1021.pdf in September 2011.

Đinh Phi Hổ et al. (2008), Kinh tế phát triển: Lý thuyết và thực tiễn, HCMC: Thống Kê Publisher.

Đặng Tú Lan (2002), "Những nhân tố ảnh hưởng tới việc giải quyết việc làm ở nước ta", Lý luận chính trị (December), retrieved from http://tainguyenso.vnu.edu.vn/jspui/bitstream/123456789/ 2491/1/20_giai_quyet_viec_lam.pdf on June 17, 2013.

GSO (2013a), Báo cáo điều tra lao động và việc làm 2012, retrieved from http://www.gso.gov.vn/default.aspx?tabid=512\&idmid=6 on April 2, 2014

GSO (2013b), Dân số và lao động, retrieved from http://www.gso.gov.vn/default.aspx? tabid=427\&idmid=3, ngày 27/03/2014 on March 27, 2014

Herman, E. (2011), "The Impact of Economic Growth Process on Employment in European Union Countries”, Romanian Economic Journal, 14(42): 47-67.

Kapsos, S. (2005), "The Employment Intensity of Growth: Trends and Macroeconomic Determinants", Labor Markets in Asia: Issues and Perspectives, 143-201, retrieved from http://www.ilo.org/wcmsp5/groups/public/@ed_emp/@emp_elm/documents/publication/wcms_ 143163.pdf on Sep. 15, 2013.

Padalino, S. \& M. Vivarelli (1997), "The Employment Intensity of Economic Growth in the G-7 Countries”, International Labour Review, 136(2): 191-213.

Phan Thúc Huân (2006), Kinh tế phát triển, Hà Nội: Thống Kê Publisher.

Schmid, G. (2008), Full Employment in Europe: Managing Labour Market Transitions and Risks, MA: Edward Elgar.

Seyfried, W. (2003), "Examining the Relationship Between Employment and Economic Growth in the Ten Largest States", Southwestern Economic Rewiew, retrieved from https://www.cis.wtamu.edu/home/index.php/swer/article/view/79/73 on July 20, 2013

Todaro, M. P \& S. C. Smith (2009), Economic Development (1 $11^{\text {th }}$ ed.), Prentice Hall.

Vietnam's Government (2011), Chiến lự̛c phát triển kinh tế xã hội giai đoạn 2011 - 2020, Hà Nội.

Vietnam's National Assembly (2012), Bộ luật lao động, available at http://www.chinhphu.vn/portal/ page/portal/chinhphu/hethongvanban?class_id=1\&mode=detail\&document_id=163542, retrieved on March 28, 2014 